Ilmu Pertanian (Agricultural Science)

Vol. 4 No. 2 August, 2019: 91-97

Available online at http://journal.ugm.ac.id/jip

DOI: doi.org/10.22146/ipas.44099

ILMU PERTANIAN
(AGRICULTURAL SCIENCE)

\title{
The Effect of Furrow Containing Organic Matters to Upland Rice (Oryza sativa L.) Growth and Yield in Agroforestry System with Kayu Putih
}

\author{
Puji Lestari Tarigan ${ }^{1 *}$, Tohari ${ }^{1}$ and Priyono Suryanto ${ }^{2}$ \\ ${ }^{1}$ Department of Agronomy, Faculty of Agriculture, Universitas Gadjah Mada \\ Jln. Flora no. 1, Bulaksumur, Sleman, Yogyakarta 55281, Indonesia \\ ${ }^{2}$ Department of Silviculture, Faculty of Forestry, Universitas Gadjah Mada \\ Jln. Agro no. 1, Bulaksumur, Sleman, Yogyakarta 55281, Indonesia \\ *Corresponding author: tari_siriuz@ymail.com
}

Received: 11 $1^{\text {st }}$ March 2019; Revised: 06 ${ }^{\text {th }}$ July 2019; Accepted: 10 ${ }^{\text {th }}$ July 2019

\begin{abstract}
This research aimed to determine the effects of the furrow system containing organic matter for rainfed on the growth and yield of several cultivars of upland rice in agroforestry system with white paperbark trees. The research was conducted in Petak 83 Resort Pengelolaan Hutan (RPH) Menggoran, Bagian Daerah Hutan (BDH) Playen, Kesatuan Pengelolaan Hutan (KPH) Yogyakarta from March to August 2018. The experimental design applied was the strip plot design. The vertical factor was the furrow system of treatment consisting of 2 levels, i.e. without furrow + without organic matter and furrow + organic matters. The horizontal factor was the cultivar of upland rice consisting of 3 cultivars, i.e. Situ Patenggang, Situ Bagendit, and Ciherang. The collected data were analyzed by analysis of variance (ANOVA) applying a level of significance $\alpha=5 \%$. Should the significant differences among treatments were found, further analysis was carried out by applying the Tukey's HSD (Honestly Significant Difference) at 5\% levels. The result showed that furrow system containing organic matter was able to support plant growth on dry land. Cultivar Situ Patenggang gave the best response of growth and production under drought stress. Cultivar Situ Patenggang treated with furrow containing organic matter showed the best result in CGR, total root length, total chlorophyll content, number of panicles, number of spikelet per panicle, 1000 grain weight and estimated productivity.
\end{abstract}

Keywords: Rainfed, furrow, upland rice, white paperbark trees, agroforestry.

\section{INTRODUCTION}

Rice has become a staple food for more than half of the world's population. In Indonesia, rapid population growth is increasing the rice needs. The source of national rice production comes from paddy and upland rice. However, rice development has several obstacles, especially in paddy fields where irrigation networks are not maintained, such as land degradation due to the conversion of paddy fields. Indonesian agricultural statistics show that in 2014-2015, the area of paddy fields decreased by 18,686 ha. The conversion of the function of agricultural land to non-agricultural use causes a decline in crop production. Furthermore, declining production will disrupt food availability.

The conversion of agricultural land occurs due to several factors, namely: 1) external factors, such as the dynamics of urban growth, demography, and economy; 2) internal factors, affected by the socioeconomic conditions of household users of agricultural land, and 3) policy factors, which are regulatory aspects issued by the central and regional governments relating to changes in the function of agricultural land (Lestari, 2009). Land conversion does not only occur on agricultural land, but also on forest. Deforestation rate in 2016-2017 occurred at 0.5 million ha. This figure is lower than the previous year, but the conversion of forest land, including agricultural land, will have a negative impact on the environment. The condition of land without forest cover will decrease soil fertility, decrease biodiversity, lead to erosion, and disrupt the hydrological functions.

Upland rice is one of the national contributor rice productions, which is relatively small developed. Upland rice productivity reaches only 3.3 tons.ha ${ }^{-1}$, 
lower than paddy which reaches 5.3 tons.ha ${ }^{-1}$. In addition, the low productivity is due to the low area of upland rice, which is only about $7 \%$ of the national harvest area (Kementerian Pertanian, 2016).

Cultivar Situ Patenggang can reach a production of 4.6 tons. $^{-1} \mathrm{a}^{-1}$ dry-miling rice. This cultivar is also drought tolerant and resistant to blast disease. Meanwhile, cultivar Situ Bagendit can reach a production of 4 ton.ha ${ }^{-1}$ (Balai Besar Penelitian Tanaman Padi, 2007). Those superior cultivars are suitable developed in upland areas. The lowland rice cultivar Ciherang, which can grow on dry land with shifting cultivation in the Pematang Sawah area, Tanggamus Regency, produces yields of 3.5-4 tons.ha-1 (Hafif, 2016).

Agricultural development on forest stand has been being paracticed for a long time, known as the agroforestry system. This system develops according to natural conditions, market needs and in line with the development of people's experience from generation to generation. The development of this system has positive impact on economic, social and environmental. Upland rice, corn, and soybeans are the potential crops to be developed in forest area. The development of these commodities is one of the strategies of the Ministry of Agriculture to achieve food self-sufficiency.

Agroforestry is a land use system that supports sustainable agriculture, which has a variety of production contributions and has a conservative function on the environment and social conditions, as to guarantee the economy and food security (FAO, 1989). Drought stress is the main factor that must be avoided on dry land cultivation because water is an important factor for plants, especially in the generative phase. Upland rice requires adequate water availability in the root zone. In dry land, soil moisture depends on the rainfall. To optimize water availability and soil moisture, rainwater harvesting is necessary. Rainwater harvesting is a technique of collecting rainwater during high rainfall, then it can be used when rainfall is low. It is minimizing surface flow of rainwater.

Currently, the furrow has only been used as drainage but has not been used to store water. The use of furrow can be optimized to be used as rain-water storages, supported by organic matter. Organic matter is a material from the rest of living things. Organic matter can absorb water with a capacity that exceeds its weight. The addition of organic matter is expected to increase the water storability to increase growth and yield of upland rice, in agroforestry system with white paperbark trees.

\section{MATERIALS AND METHODS}

The research was conducted from March to August 2018 in Petak 83 Menggoran Forest Resort (RPH Menggoran), Playen Forest Section (BDH Playen), and Yogyakarta Forest Management District (KPH Yogyakarta), Gunung Kidul Regency, Daerah Istimewa Yogyakarta. The whote paperbark trees were planted by KPH Yogyakarta with planting space of $4 \times 2 \mathrm{~m}$. Organic matter was obtained from the remaining plants around the land.

The field experiment was arranged in strip plot design, i.e. 1) furrow as vertical factor, consisting of without furrow + without organic matters and with furrow + organic matter and 2) cultivar as horizontal factor, consisting of Situ Patenggang, Situ Bagendit, and Ciherang.

Plant maintenance were fertilizing, weeding, pest management, and disease control. Fertilization was given in three times. The fertilizers applied at 2 WAP (Weeks after planting) were Urea 100 g.plot ${ }^{-1}$, SP-36 26.5 g.plot ${ }^{-1}$ and $\mathrm{KCl} 62$ g.plot ${ }^{-1}$, while at 5 WAP were Urea 125 g.plot ${ }^{-1}$ and $\mathrm{KCl} 62$ g.plot $^{-1}$, whereas at 8 WAP were Urea 125 g.plot $^{-1}$, SP-36 26.5 g.plot $^{-1}$ and $\mathrm{KCl} 62$ g.plot $^{-1}$. Weeding, pest management and disease control done according to the integrated pest and disease management. Weeding was done using mechanical method by farming tools, pest control using mechanical method by setting up nets and disease control using Blast Gone 75WP 300 g.ha $^{-1}$.

The observation included rainfall, soil moisture, growth components, physiological characteristic and yield component. The data from observations were analyzed using Analysis of Variance (ANOVA) according to split plot design using SAS 9.4. software for Windows. Should the differences between factors were significant, means were compared using the Tukey's HSD (Honestly Significant Difference) at $5 \%$ levels.

\section{RESULTS AND DISCUSSION}

\section{Rainfall and Soil Moisture}

The upland rice growth depends on rainwater, and drought is the main limiting factor. Water requirement during planting period is important to considered. Rainfall decreases during growing season (Figure 1). Low rainfall in rainfed farming can cause low production and even yield loss.

Water deficit that occurs at certain stages of the growth period causes the plant response to be different, depending on the sensitivity of the plant at that stage 


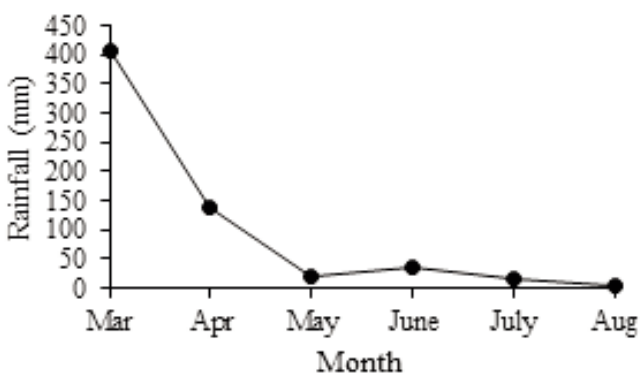

Figure 1. Rainfall during research (Source: BMKG STAKLIM, Yogyakarta)

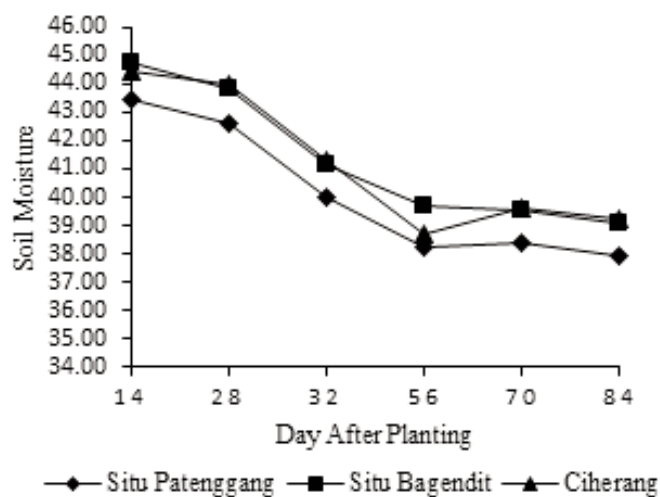

Figure 2. Soil moisture content without furrow and without organic matter

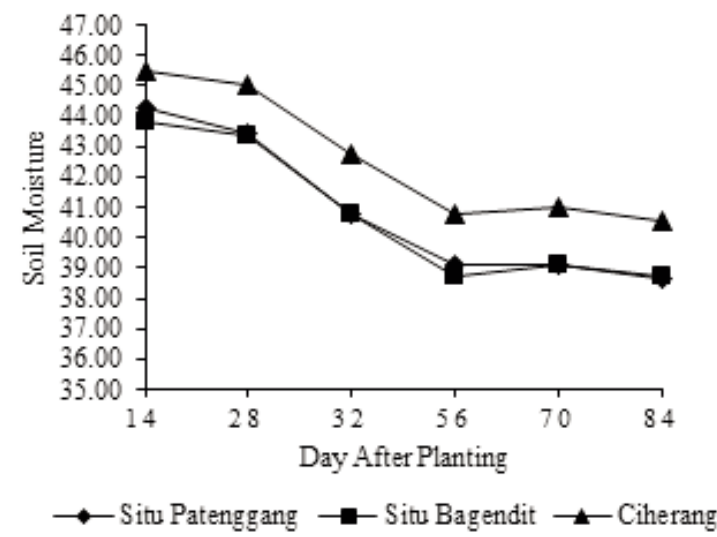

Figure 3. Soil moisture content with furrow and organic matter

of growth. In general, plants are more sensitive to water deficits at germination, flowering and the initial formation of yield than at the beginning of vegetative and ripening (Munir, 2012; Fuadi et al.., 2016).

As described in Figure 2 and 3, soil moisture rate condition without furrow and organic matter was $37 \%-44 \%$ and with furrow and organic matter was $38 \%-45 \%$. The application of furrow system with organic matter improved water absorption capacity, which means increasing infiltration, reducing rainwater run off, and storing water longer.

Organic matter or plant litter is able to increase infiltration and percolation (Arsyad, 2000). When rainfall is lower, soil with furrow and organic matter can contain more water. Water is supplied for plant through a storage system, in which rainwater is collected and absorbed by organic matter.

Rice is sensitive to drought stress. Lack of water can reduce physiological activity and cause negative impact on plant growth and reproduction (Bray, 2001; Sujinah and Jamil, 2016). Water requirement for rice at the beginning of vegetative phase is the most critical, where the vegetative phase is the phase of formation of active tillers and maximum tillers (Vergara, 1976; Ezward et al.., 2018).

\section{Growth Component}

Plant growth is indicated by the increases in size caused by the accretion of number of cells. There was positive interaction effect between the application furrow and cultivars on each variable, except on leaf area index and net assimilation rate.

As described in Table 1, cultivar Situ Bagendit with furrow and organic matter had the highest leaf area, which was not significantly different compared with cultivar Situ Patenggang with furrow and organic matter. Cultivar Situ Patenggang without furrow and without organic matter had the highest net assimilation rate, which was not significantly different compared with cultivar Situ Bagendit without furrow and without organic. Meanwhile, cultivar Situ Patenggang with furrow and organic matter showed the highest value of crop growth rate.

Assimilate accumulation, as dry weight, in certain time is known as net assimilation rate. Crop growth rate is a result of assimilate translocation to form plant organs. Further, leaves are formed, and they are increasing in number and area. On the other hand, dry weight is affected by the leaf area, in which photosynthesis occurs. Leaves absorb sunlight 
Table 1. The interaction of furrow and varieties on leaf area index (LAI), net assimilation rate (NAR), crop growth rate (CGR) and total root length.

\begin{tabular}{|c|c|c|c|c|}
\hline \multirow{2}{*}{ Treatment } & \multicolumn{3}{|c|}{ Varieties } & \multirow{2}{*}{ Mean } \\
\hline & Situ Patenggang & Situ Bagendit & Ciherang & \\
\hline Leaf Area Index & \multicolumn{4}{|c|}{$\left(\mathrm{cm}^{2}\right)$} \\
\hline Without furrow + without organic matter & $2.99 \mathrm{c}$ & $2.74 \mathrm{~cd}$ & $2.32 \mathrm{~d}$ & $2.68 \mathrm{~b}$ \\
\hline Furrow + organic matter & $4.60 \mathrm{ab}$ & $4.89 \mathrm{a}$ & $4.05 \mathrm{~b}$ & $4.51 \mathrm{a}$ \\
\hline Mean & $3.80 \mathrm{a}$ & $3.81 \mathrm{a}$ & $3.19 \mathrm{~b}$ & + \\
\hline Net Assimilation Rate & \multicolumn{4}{|c|}{$\left(\mathrm{g} . \mathrm{cm}^{-2} \cdot\right.$ week $\left.^{-1}\right)$} \\
\hline Without furrow + without organic matter & $0.2577 \mathrm{a}$ & $0.2532 \mathrm{a}$ & $0.1973 \mathrm{~b}$ & $0.2360 \mathrm{a}$ \\
\hline Furrow + organic matter & $0.1940 \mathrm{~b}$ & $0.1451 \mathrm{c}$ & $0.1452 \mathrm{c}$ & $0.1615 \mathrm{~b}$ \\
\hline Mean & $0.2258 \mathrm{a}$ & $0.1991 \mathrm{~b}$ & $0.1713 \mathrm{c}$ & + \\
\hline Crop Growth Rate & \multicolumn{4}{|c|}{$\left(\mathrm{g} . \mathrm{cm}^{-2} \cdot\right.$ week $\left.^{-1}\right)$} \\
\hline Without furrow + without organic matter & $0.0138 \mathrm{c}$ & $0.0124 \mathrm{~d}$ & $0.0097 \mathrm{e}$ & $0.0119 \mathrm{~b}$ \\
\hline Furrow + organic matter & $0.0159 \mathrm{a}$ & $0.0149 \mathrm{~b}$ & $0.0124 \mathrm{~d}$ & $0.0145 \mathrm{a}$ \\
\hline Mean & $0.0148 \mathrm{a}$ & $0.0137 \mathrm{~b}$ & $0.00111 \mathrm{c}$ & + \\
\hline Total root length & \multicolumn{4}{|c|}{$(\mathrm{cm})$} \\
\hline Without furrow + without organic matter & $181.203 \mathrm{~b}$ & $165.378 \mathrm{c}$ & $127.541 \mathrm{e}$ & $158.041 \mathrm{~b}$ \\
\hline Furrow + organic matter & $199.614 \mathrm{a}$ & $186.698 \mathrm{~b}$ & $155.475 \mathrm{~d}$ & $180.596 \mathrm{a}$ \\
\hline Mean & $190.408 \mathrm{a}$ & $176.038 \mathrm{~b}$ & $141.508 \mathrm{c}$ & + \\
\hline Total chlorophyll content & \multicolumn{4}{|c|}{$\left(\mathrm{mg} \cdot \mathrm{m}^{-3}\right)$} \\
\hline Without furrow + without organic matter & $30.273 \mathrm{bc}$ & $27.3203 \mathrm{c}$ & $21.116 \mathrm{~d}$ & $26.237 \mathrm{~b}$ \\
\hline Furrow + organic matter & $40.785 \mathrm{a}$ & $38.4663 \mathrm{a}$ & $31.708 \mathrm{~b}$ & $36.987 \mathrm{a}$ \\
\hline Mean & $35.5293 \mathrm{a}$ & $32.8933 \mathrm{~b}$ & $26.412 \mathrm{c}$ & + \\
\hline
\end{tabular}

Remark: Means followed by the same letters in the same column and row are not significantly different according to Tukey's HSD at $5 \%$ levels. $(+)$ indicated an interaction between the factors tested.

during photosynthesis, thus, higher leaf area is needed to produce more assimilate. Along with growth stage, an increase in leaf area will change or reduce the photosynthesis rate, so the assimilation decreases. This is because the leaves are covering each other. However, this factor is also affected by canopy growth and plant spacing.

Rice plant needs around 4-8 leaf area index to absorb light properly (Yoshida, 1981). A lower leaf area index observed in this tudy was caused by water deficit due to the decrease in rainfall (Table 1). Water is the largest component of a plant, composing around $85-90 \%$ of protoplasm and functioning as an important reagent in photosynthesis and other hydraulic processes (Slatyer, 1967). Plant absorbs nutrient to grow, forming organs. Limited amount of water leads to closed stomata, a decrease in leaf area and a decrease in photosynthesis rate.

Soil moisture is an important factor affecting the level of availability nutrient in the soil and nutrient uptake by plants (Kramer, 1969). Infiltration detained by furrow containing organic matter is able to increase soil moisture. Plant growth on dry land should have long root to access water. Root length is related to the ability of plant to absorb water and nutrients. According to Chang and Baker (1986); Basyir et al. (1995), drought tolerant cultivars usually have long and thick roots.

As described in Table 1, there was positive interaction effect between the application of furrow and cultivars on the total root length. Cultivar Situ Patenggang with furrow and organic matter had the highest total root length.

There is an imbalance between water absorption and transpiration since drought stress occurs. The soil surface starts drying, but deep soil horizon may remain wet and be able to supply water (Yoshida, 1981). Furrow containing organic matter can increase the water amount in soil horizon. However, this certainly depends of rainfall volume.

\section{Plant Physiology Chlorophyll Content}

There was positive interaction effect between the application of furrow and cultivars on the total chlorophyll content. Cultivar Situ Patenggang with 
furrow and organic matter had the highest total chlorophyll content, which was not significantly different from cultivar Situ Bagendit with furrow and organic matter (Table 1).

The response of plants to water shortages is generally indicated by a decrease in leaf chlorophyll concentration. Decrease in chlorophyll content in water-deficient plants are related to the activity of photosynthetic devices, resulting in a decrease in the rate of plant photosynthesis (Ai and Banyo, 2011; Felania, 2017). Chlorophyll is the main factor for photosynthesis. Water deficit in dry land can reduce chlorophyll content. This is one of the indications of drought stress. Nutrition uptake is affected by water absorption, therefore a low rate of chlorophyll synthesis could be caused by low $\mathrm{N}$ and $\mathrm{Mg}$ uptake.

Chlorophyll is the main component of chloroplast and the relative chlorophyll content is positively correlated with the rate of photosynthesis ( Li et al., 2006; Ai and Banyo, 2011). Obstructed chlorophyll synthesis is caused by limited amount of water due to decreasing photosynthesis rates (Hendriyani and Setiari, 2009).

\section{Proline Content}

Proline is nonessential amino acid which is included to osmo-protectant compatible osmo-lyte. The accumulation of proline is a mechanism as response to environmental stress. There was no interaction effect between the application of furrow and cultivars on

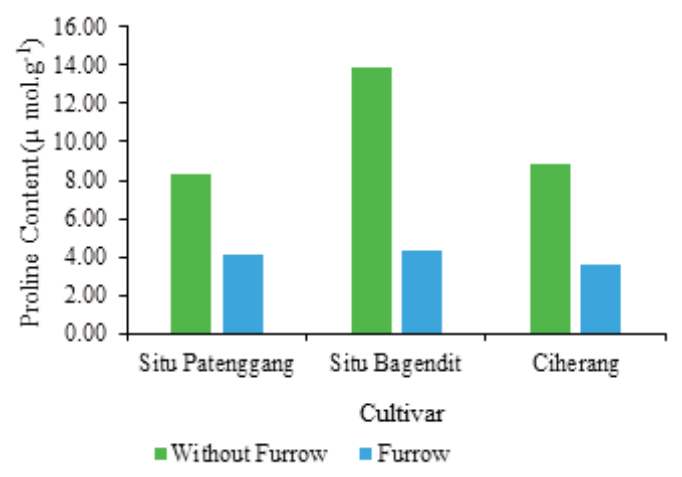

Figure 4. The effect of furrow and varieties on proline content

Table 2. The interaction of furrow and varieties on number of panicle, number of spikelet per panicle, 1000 grain weight and estimated productivity

\begin{tabular}{|c|c|c|c|c|}
\hline \multirow{2}{*}{ Treatment } & \multicolumn{3}{|c|}{ Varieties } & \multirow{2}{*}{ Mean } \\
\hline & Situ Patenggang & Situ Bagendit & Ciherang & \\
\hline Number of panicle & \multicolumn{4}{|c|}{$\left(\mathrm{cm}^{2}\right)$} \\
\hline Without furrow + without organic matter & $9.24 \mathrm{c}$ & $8.23 \mathrm{~d}$ & $6.5 \mathrm{e}$ & $7.94 \mathrm{~b}$ \\
\hline Furrow + organic matter & $12.94 \mathrm{a}$ & $11.74 \mathrm{~b}$ & $9.69 \mathrm{c}$ & $11.45 \mathrm{a}$ \\
\hline Mean & $11.09 \mathrm{a}$ & $9.98 \mathrm{~b}$ & $8.02 \mathrm{c}$ & + \\
\hline Number of spikelet per panicle & \multicolumn{4}{|c|}{$\left(\right.$ g.cm ${ }^{-2} \cdot$ week $\left.^{-1}\right)$} \\
\hline Without furrow + without organic matter & $75.07 \mathrm{bc}$ & $68.17 \mathrm{c}$ & $51.96 \mathrm{~d}$ & $65.07 \mathrm{~b}$ \\
\hline Furrow + organic matter & $96.80 \mathrm{a}$ & $91.85 \mathrm{a}$ & $76, .64 \mathrm{~b}$ & $88.43 \mathrm{a}$ \\
\hline Mean & $85.94 \mathrm{a}$ & $80.01 \mathrm{~b}$ & $64.30 \mathrm{c}$ & + \\
\hline 1000 grain weight & \multicolumn{4}{|c|}{ (g) } \\
\hline Without furrow + without organic matter & $10.02 \mathrm{~b}$ & $9.22 \mathrm{c}$ & $7.13 \mathrm{~d}$ & $8.79 \mathrm{~b}$ \\
\hline Furrow + organic matter & $15.25 \mathrm{a}$ & $14.27 \mathrm{a}$ & $11.94 \mathrm{~b}$ & $13.82 \mathrm{a}$ \\
\hline Mean & $12.64 \mathrm{a}$ & $11.74 \mathrm{~b}$ & $9.53 \mathrm{c}$ & + \\
\hline Estimated productivity & \multicolumn{4}{|c|}{$\left(\right.$ ton.ha $\left.^{-1}\right)$} \\
\hline Without furrow + without organic matter & $0.92 \mathrm{c}$ & $0.84 \mathrm{c}$ & $0.63 \mathrm{c}$ & $0.80 \mathrm{~b}$ \\
\hline Furrow + organic matter & $2.72 \mathrm{a}$ & $2.53 \mathrm{ab}$ & $2.10 \mathrm{~b}$ & $2.45 \mathrm{a}$ \\
\hline$\overline{\text { Mean }}$ & $1.82 \mathrm{a}$ & $1.68 \mathrm{~b}$ & $1.37 \mathrm{c}$ & + \\
\hline
\end{tabular}

Remark: Means followed by the same letters in the same column and row are not significantly different according to Tukey's HSD at $5 \%$ levels. $(+)$ indicated an interaction between the factors tested. 
the proline content. The proline content in cultivar Situ Bagendit without furrow and without organic matter was higher than that in other cultivars, which was actually not significantly different (Figure 4).

Proline is an osmoticum compound that plays a role in increasing the resistance to water stress from its environment so that it is accumulated under low water availability conditions (Mathius et al., 2001; Novenda and Nugroho, 2016). The accumulation of proline in drought tolerant plant is higher than in the susceptible plant (Yoshida et al., 1997). Therefore, cultivar Situ Bagendit is considered to be more tolerant to drought stress than other cultivars. Without furrow, there was no water supply as no water stored. The increase in compatible osmolytes is the osmotic adjustment mechanism.

In the osmoregulation (osmotic adjustment) occurs regulation of osmotic potential in cells by increasing or decreasing intracellular potentials solute to approaching medium surroundings potential osmotic (Turner and Jones, 1980).

\section{Productivity Component}

In dry land, drought stress can occur in each plant growth stage. Water quantity is important for plant activities. Stress that occurs in early generative phase affects the productivity component and yield.

There was positive interaction effect between the application of furrow and cultivars on the productivity component. Cultvar Situ Patenggang with furrow and organic matter had the highest number of panicles, number of spikelet per panicle, 1000 grain weight, and estimated productivity, which was not significantly different compared with cultivar Situ Bagendit under the same treatment.

Rice is sensitive to drought stress, especially during flowering (Lafitte, 2003; Ningrum, 2014). Stress conditions usually result in less grain production. The mechanism of drought resistant species is to complete the life cycle, maintain water potential, or continue to generative phase even though low in production.

The vegetative and generative phases are influenced by water availability because it can reduce the viability of pollen and cause sterility, furthermore affecting the grain yield (Liu et al., 2003; Rangga, 2010; Afrianingsih et al., 2018). Drought occurring in flowering and grain filling phase inhibits plant development and grain produced (Lubis et al., 2013).

Water plays an important role in generative phase, principally in grain filling. Number of panicles is related to the number of spikelet per panicle, 1000 grain weight and productivity.

Grain yield is determined by the yield component. The ability to produce panicle and productivity of each panicle determine total productivity (Mohanan and Mini, 2008).

Panicle length and grain yield have correlation, so that cultivars able to produce longer panicle are expected to increase crop production (Sutaryo B, A. and Purwantoro, 2005; Sitinjak and Idwar, 2015).

Tolerance is plant ability to continue function despite stress (Mitra, 2001). Furrow system containing organic matter was able to support plant growth on the dry land. Cultivar Situ Patenggang had the highest adaptation in growth and productivity under the drought stress.

\section{CONCLUSIONS}

The application of furrow system containing organic matter to rice cultivar Situ Patenggang showed the best result in CGR, total root length, total chlorophyll content, number of panicles, number of spikelet per panicle, 1000 grain weight and estimated productivity.

\section{REFERENCES}

Afrianingsih, S., U. Susanto, and N. R. Ardiarini. 2018. Toleransi genotipe padi (Oryza sativa L.) pada fase vegetatif dan fase generatif terhadap cekaman kekeringan. J. Prod. Tan., 6:355-63.

Ai, N, S and Y. Banyo. 2011. Konsentrasi klorofil daun sebagai indikator kekurangan air pada tanaman. J. Ilm. Sains, 11: 166-73.

Arsyad, S. 2000. Konservasi tanah dan air. Bogor: Penerbit IPB.

Balai Besar Penelitian Tanaman Padi. 2007. Deskripsi varietas padi. Jakarta: Badan Penelitian dan Pengembangan Pertanian.

Basyir, A., Punarto, Suyanto, and Supriyatin. 1995. Padi gogo. Malang: Balai Penelitian Tanah.

Bray, E. A. 2001. Plant response to water-deficit stress. Chicago: Encyclopedia of Life Sciences.

Ezward, C., S. Efendi, and J. Makmun. 2011. Pengaruh frekuensi irigasi terhadap pertumbuhan dan hasil padi (Oryza sativa L.). J. Agro, 1:17-24.

FAO. 1989. Forestry and food security. FAO Forestry Paper 90. http:// www.fao.org/3/ T0178E/ T0178E00.html/.

Felania, C. 2017. Pengaruh ketersediaan air terhadap pertumbuhan kacang hijau (Phaceolus radiatus), p. 131-38. In: Seminar Nasional Pendidikan 
Biologi. Yogyakarta: Jurusan Pendidikan Biologi, Fakultas MIPA, Universitas Negeri Yogyakarta.

Fuadi, N. A., M. Y. J. Purwanto, and S. D. Tarigan. 2016. Kajian kebutuhan air dan produktivitas air padi sawah dengan sistem pemberian air secara SRI dan konvensional menggunakan irigasi pipa. J. Irig., 11: 23-32.

Hafif, B. 2016. Optimasi potensi lahan kering untuk pencapaian target peningkatan produksi padi satu juta ton di provinsi Lampung. J. Litbang Pert., 35:81-88.

Hendriyani, I. S and N. Setiari. 2009. Kandungan klorofil dan pertumbuhan kacang panjang (Vigna sinensis) pada tingkat penyediaan air yang berbeda. J. Sains and Math., 17: 145-50.

Sujinah and A. Jamil. 2016. Mekanisme respon tanaman padi terhadap cekaman kekeringan dan varietas toleran. J. Ilmu Peng. Tek. Tan. Pang., 11: 1-8.

Kementrian Pertanian. 2016. Data lima tahun terakhir. http://www.pertanian.go.id/home/?show $=$ page\&act $=$ view\&id $=61$.

Kramer, P. J. 1969. Plant and soil water relationships: Modern synthesis. New York: Mc. Graw-Hill, Inc.

Lestari, T. 2009. Dampak konversi lahan pertanian bagi taraf hidup petani. Skripsi. Bogor: Institut Pertanian Bogor.

Liu, F., Jensen and M. N. Andersen. 2003. Drought stress effect on carbohydrate in soybean leaves and pods during early reproductive development: Its implication in altering pod set. J. Field Crop Res., 86: 1-13.

Lubis, E., Z. Harahap, Suwarno, M. Diredja and H. Siregar. 2013. Perbaikan varietas padi gogo untuk wilayah perhutanan beriklim kering. $\mathrm{p}$. 1-13. In: Risalah hasil penelitian tanaman pangan: Balai Besar Biogen, Bogor.
Mitra, J. 2001. Genetics and genetic improvement of drought resistance in crop. J. Plants Curr. Scie. 80: 758-63.

Mohanan, K.V. and C. B. Mini. 2008. Relative contribution of rice tillers of different status towards yield. J. Plant Breed. Gen., 2: 9-12.

Ningrum, D. K. 2014. Pengaruh kekeringan terhadap produktivitas padi varietas Ciherang, Inpari 10 dan Inpari 13. Skripsi. Institut Pertanian Bogor. Bogor.

Novenda I. L and S. A. Nugroho. 2016. Analisis kandungan prolin tanaman kangkung (Ipomoea reptana Poir), bayam (Amaranthus spinosus), dan ketimun (Cucumis sativus L.). J. Panc., 5: 223-34.

Sitinjak, H. and Idwar. 2005. Respon berbagai varietas padi sawah (Oryza sativa L.) yang ditanam dengan pendekatan teknik budidaya jajar legowo dan sistem tegel. J. Onl. Mah. Fap., 2: $1-15$.

Slatyer, R. 1967. Plant water relationships. New York: Academic Press.

Turner, N. C. and M. M. Jones. 1980. Turgormaintenance by osmotic adjustment: A review and evaluation, p. 87-103. In: Turner, N. C. and Kramer P.J. (eds). Adaptation of plant to water and high temperature: John Wiley and Sons, New York.

Yoshida, N., Dorta M. L., Ferreira A. T., Oshiro M. E., Mortara R. A., and Acosta-Serrano A. 1997. Removal of sialic acid from mucin-like surface molecules of Trypanosoma cruzi metacyclic trypomastigotes enhances parasite-host cell interaction. J. Mol. Bio. Par., 84: 57-67.

Yoshida, S. 1981. Fundamental of Rice Crop Science. Philippines: The International Rice Research and Institute. 